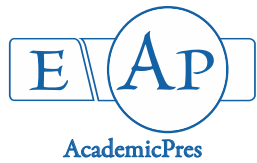

\title{
Growth and Yield Responses of Cucumber (Cucumis sativum L.) to Different Nitrogen Levels of Goat Manure in the Humid Ultisols Environment
}

\author{
Kolawole E. LAW-OGBOMO*, Agbonsalo U. OSAIGBOVO \\ University of Benin, Faculty of Agriculture, Department of Crop Science, Benin City, \\ Nigeria; edomwonyi.law-ogbomo@uniben.edu ( ${ }^{*}$ corresponding author)
}

\begin{abstract}
A field trial was conducted at the Experimental Farm of the University of Benin, Benin City, Nigeria between May and July in both 2015 and 2016 to evaluate growth and yield responses of cucumber (Cucumis sativum L.) to different nitrogen levels of goat manure. The experiment was laid out in a randomized complete block design involving five treatments and replicated three times. The treatments were cured goat manure applied at levels of $0,100,200,300$ and $400 \mathrm{~kg} \mathrm{~N} \mathrm{ha}^{-1}$. Growth parameters were collected on vine length $(\mathrm{cm})$, vine girth $(\mathrm{cm})$, number of branches, number of leaves and leaf area index (LAI). Yield parameters assessed were fruit length $(\mathrm{cm})$, fruit girth $(\mathrm{cm})$, number of fruits per plant and fruit yield $\left(\mathrm{t} \mathrm{ha} \mathrm{a}^{-1}\right)$. Goat manure application significantly $(\mathrm{P}<0.05)$ influenced growth parameters positively, which led to the enhancement of the fruit yield. Goat manure application levels of $200\left(20.85 \mathrm{t} \mathrm{ha}^{-1}\right), 300\left(20.85 \mathrm{t} \mathrm{ha}^{-1}\right)$ and $400\left(26.21 \mathrm{t} \mathrm{ha}^{-1}\right) \mathrm{kg} \mathrm{N} \mathrm{ha}^{-1} \mathrm{had}^{-1}$ similar $(\mathrm{P}>0.05)$ fruit yield, but significantly $(\mathrm{P}<0.05)$ higher than those of $0\left(12.34 \mathrm{t} \mathrm{ha}^{-1}\right)$ and $10\left(16.96 \mathrm{t} \mathrm{ha}^{-1}\right) \mathrm{kg} \mathrm{N} \mathrm{ha}^{-1}$. It thus recommended that goat manure at $20 \mathrm{~kg} \mathrm{~N} \mathrm{ha}^{-1}$ is more appropriate for cucumber production in the humid ultisols environment.
\end{abstract}

Keywords: fruit yield; leaf area index; number of leaves; plant height; vine length

\section{Introduction}

Cucumber (Cucumis sativum L.) is an important fruit vegetable with great economic potentials, as well as a medicinal plant and source of industrial raw material. Cucumber is effective in regulating blood pressure and is known to have anti- cancer properties. Daily consumption of cucumber can be regarded as the remedy for chronic constipation. The juice of cucumber is a valuable food in the treatment of hyperacidity, gastric and duodenal ulcers. It is used in skin and hair care. It is a rich source of minerals and vitamins (Eifediyi and Remison, 2009). It is a popular fresh market vegetable for making salads. The fruits can be used for slicing, prickling etc. and also in making Indian pickle and chutney.

Despite the economic importance of this crop, its yield per hectare is very low. This could be, among other factors, due to unimproved cultural practices which include nonuse of fertilizer, inappropriate plant population, varying amount of moisture.

Goat manure is a potential source of nutrients and also a potential benefit to soil amelioration, especially for communal farms who cannot afford fertilizers. Goat manure is currently been wasted and constitute environmental nuisance, even though it can be converted to wealth by using it as organic fertilizer. However, getting the maximum value out of the manure requires applying it at proper rates and frequency in conjunction to a particular soil (Pahla et al., 2013).

Considering the economic importance of cucumber, the unaffordability of inorganic fertilizer by small holder farmers, as well as the availability of goat manure in the country, hence, the present study was carried out to evaluate the effect of goat manure application on the growth and yield of cucumber.

\section{Materials and Methods}

\section{Studyarea}

The field trial was conducted during the early season (May - July) of 2015 and 2016 at the Experimental site of the Faculty of Agriculture, University of Benin, Benin City. (latitude $6^{\circ} 19^{\prime} \mathrm{N}$ and longitude $5^{\circ} 39^{\prime} \mathrm{E}$ ) with an altitude range of $152 \mathrm{~m}$ above the sea level in the rain forest ecological zone of Nigeria. The area has a bimordal rainfall with mean annual total of over $2,000 \mathrm{~mm}$ and mean daily 
temperature of $26.5^{\circ} \mathrm{C}$ (EADP, 1995). The experimental site was previously cultivated with yam, maize and other crops. The dominant vegetation at the experimental site was of Panicum maximum, Chromolana odorata and Mimosa spp. The soil order of the studied site was ultisols and sandy loam texturally. The soil on laboratory analysis had $\mathrm{pH}$, organic carbon, total nitrogen, exchangeable $\mathrm{Ca}, \mathrm{Mg}, \mathrm{K}, \mathrm{Na}$ and exchangeable acidity of $5.70,18.56 \mathrm{~g} \mathrm{~kg}^{-1}, 0.87 \mathrm{~g} \mathrm{~kg}^{-1}$, $5.40 \mathrm{mg} \mathrm{kg}{ }^{-1}, 0.78 \mathrm{cmol} \mathrm{kg}^{-1}, 0.35 \mathrm{cmol} \mathrm{kg}{ }^{-1}, 0.24 \mathrm{cmol} \mathrm{kg}^{-1}$, $0.20 \mathrm{cmol} \mathrm{kg}^{-1}$ and $0.25 \mathrm{cmol} \mathrm{kg}^{-1}$ respectively. The goat manure was cured under shade for four weeks and analyzed for its chemical composition. The proximate nutrient composition of the goat manure was $\mathrm{pH} 6.40$, organic carbon $30.12 \mathrm{~g} \mathrm{~kg}^{-1}$, total $\mathrm{N} 22.3 \mathrm{~g} \mathrm{~kg}^{-1}$ available P $14.22 \mathrm{~g}$ $\mathrm{kg}^{-1}$, exchangeable Ca $12.84 \mathrm{cmol} \mathrm{kg}^{-1}, \mathrm{Mg} 0.66 \mathrm{cmol} \mathrm{kg}^{-1}, \mathrm{~K}$ $0.32 \mathrm{cmol} \mathrm{kg}^{-1}$, Na $0.35 \mathrm{cmol} \mathrm{kg}^{-1}$ and exchangeable acidity $0.22 \mathrm{cmol} \mathrm{kg}^{-1}$.

\section{Experimental design and field experimentation}

The experiment involved five rates of goat manure $(0$, $10,20,30$ and $40 \mathrm{~kg} \mathrm{~N} \mathrm{ha}^{-1}$ ) in a Randomized Complete Block Design (RCBD) with three replicates. The study sited has a land mark of $236.25 \mathrm{~m}^{2}(22.5 \times 10.5 \mathrm{~m})$. The site was manually cultivated using cutlass and hoe. The land was marked out with pegs and the beds were made using a spade.

Seeds of cucumber variety ('Super marketer') were sowed at the rate of 3 seeds/stand at a spacing of $90 \times 60 \mathrm{~cm}$ thinned to one seedling per stand two weeks after sowing (WAS) giving a plant population of 25 plants per plot. Alley pathway of $0.5 \mathrm{~m}$ was made for easy access to the plot. Incidence of cucumber beetles and lepidopterous insect attack were controlled by spraying with mixture of neem leaf and oil extra, 21 days after germination. Weeding was done as at when due to eliminate competition and ensure efficient use of the growth resources (water, physical space, light and nutrients).

\section{Data collection and analysis}

Data was collected for both growth and yield parameter on four randomly selected plants from the inner rows of each plot. The growth parameters were collected at 50\% flowering day on vine length $(\mathrm{cm})$, vine girth $(\mathrm{cm})$, leaf area $\left(\mathrm{cm}^{2}\right)$, leaf area index (LAI) and number of branches. At harvest, data were collected on fruit length $(\mathrm{cm})$, fruit girth $(\mathrm{cm})$, number of fruits per plant, fruit weight per plant and fruit yield $\left(\mathrm{t} \mathrm{ha}^{-1}\right)$.

Vine length: The length of the vine was measured from the ground level to the tip of the vine using a tape rule calibrated in centimeters. Mean values of three sampled plants of each plot was calculated. Vine girth $(\mathrm{cm})$ : This was taken above at a point $5 \mathrm{~cm}$ above the ground level on each of the three sampled plants using a tape rule calibrated in centimeters and the average was calculated.

Leaf area involved the measurement of the length and width of three randomly selected leaves out of three selected plants. The mean obtained was used to estimate the leaf area using the formula:

$\mathrm{LA}=0.859(\mathrm{LW})+2.7 \times$ number of leaves (Blanco and Folegatti, 2003).

Where LA = leaf area; $\mathrm{L}=$ length; $\mathrm{W}=$ width
From the leaf area, leaf area index was computed as: LAI = Leaf area/Land area (Remison, 1997)

Number of branches involved the counting of branches of each of the three sampled plants and the mean was obtained. The number of days from sowing to the time half of the plants in each plot produced visible flowers was recorded. Fruit yield was determined through the weighing of all the harvested fruits in a plot and summed up and then divided by the plot area and multiplied by the area of a hectare and was expressed in $\mathrm{tha}^{-1}$. 1)/1000

\section{i.e $\quad$ Yield $(\mathrm{kg} / \mathrm{plot}) / 12 \times 10,000\left(\mathrm{t} \mathrm{ha}^{-1}\right) / 1000$}

Fruit length was determined by measuring the fruit length from the distal to the proximal end of the harvested fruits in each plot and the average computed. The fruit girth was measured using a vernier caliper calibrated in $\mathrm{cm}$. The total number of fruits of harvested in each plot divided by total number of plants in each plot was used to estimate the number of fruits per plant. Data collected were subjected to combined analysis of variance and significant differences among treatment means were separated using the least significant differences (LSD) $(\mathrm{P}<0.05)$. Pearson's correlation will be used to test for a correlation between cucumber yield and other variables using correlation analysis of GENSTAT.

\section{Results}

The physical and chemical properties of the experimental site and chemical composition of goat manure

The soil was sandy loam and moderately acidic. It was low in organic carbon, total $\mathrm{N}$, available $\mathrm{P}$, exchangeable calcium and magnesium. The goat manure was slightly acidic with high quantity of organic carbon. It also contained appreciable quantity of plant nutrients.

\section{Growth of cucumber}

The effect of goat manure application on the growth of cucumber is presented in Table 1 . Vine length and vine girth were not significantly $(\mathrm{P}>0.05)$ influenced by the application of goat manure, as well as the rates produced. Similar vine length and vine girth values were expressed by all rates of goat manure applied. Number of branches varied significantly $(\mathrm{P}<0.05)$ with the different rates of goat manure with the highest (13.00) and lowest (9.88) number of branches obtained with the application of $400 \mathrm{~kg} \mathrm{~N} \mathrm{ha}^{-1}$ of goat manure and zero application (control), respectively. However, $400 \mathrm{~kg} \mathrm{~N} \mathrm{~kg} \mathrm{ha}^{-1}$ had similar number of branches ( $\mathrm{P}>0.05)$ with $100-300 \mathrm{~kg} \mathrm{~N} \mathrm{ha}^{-1}$. The number of leaves was most numerous in plots treated with goat manure at $400 \mathrm{~kg} \mathrm{~N} \mathrm{ha}^{-1}$; however, it was only significantly $(\mathrm{P}<0.05)$ higher than zero application (control). Goat manure application rates of 200,300 and $400 \mathrm{~kg} \mathrm{~N} \mathrm{ha}^{-1}$ resulted in similar LAI, which values were significantly $(\mathrm{P}<0.05)$ higher than those obtained at 0 and $100 \mathrm{~kg} \mathrm{~N} \mathrm{k} \mathrm{ha}^{-1}$. Plants treated with application rates of 100,200 and $300 \mathrm{~kg} \mathrm{~N} \mathrm{ha}^{-1}$ were earlier to $50 \%$ flowering than those treated with 0 and $400 \mathrm{~kg} \mathrm{~N} \mathrm{ha}^{-1}$. 
230

Table 1. Growth of cucumber (Cucumis sativum) as influenced by different rates of goat manure application at $50 \%$ flowering day

\begin{tabular}{ccccccc}
\hline Goat manure & Vine length & Vine girth & No. of branches & No. of leaves & LAI & $50 \%$ flowering day \\
\hline$\left(\mathrm{Kg} \mathrm{N} \mathrm{ha}^{-1}\right)$ & $(\mathrm{cm})$ & $(\mathrm{cm})$ & & & & \\
0 & 52.70 & 3.37 & 9.88 & 15.70 & 0.88 & 39.00 \\
100 & 56.20 & 4.33 & 10.00 & 18.00 & 1.35 & 37.67 \\
200 & 70.30 & 3.80 & 12.00 & 20.70 & 1.56 & 37.67 \\
300 & 74.10 & 4.83 & 12.00 & 28.40 & 3.04 & 37.33 \\
400 & 80.40 & 4.77 & 13.00 & 24.00 & 2.55 & 38.33 \\
$\mathrm{LSD}_{(0.05)}$ & $\mathrm{ns}$ & $\mathrm{ns}$ & 3.323 & 12.270 & 1.620 & 1.087 \\
\hline
\end{tabular}

ns - not significant at $0.05 \%$ level of probability

\section{Yield and yield component of cucumber}

The influence of goat manure application on fruit yield and its components are presented in Table 2. Fruit length of plants treated goat manure at the rates of 300 and $400 \mathrm{~kg} \mathrm{~N}$ ha ${ }^{-1}$ was significantly $(\mathrm{P}<0.05)$ longer than those of plants treated with 0,100 and $200 \mathrm{~kg} \mathrm{~N}^{-1}$ of goat manure. This distribution pattern was reflected for fruit girth and number of fruits per plant. Although plants fertilized with $400 \mathrm{~kg} \mathrm{~N}$ $\mathrm{ha}^{-1}$ had the highest fruit yield $\left(26.21 \mathrm{t} \mathrm{ha}^{-1}\right)$, it was statistically comparable with 200 and $300 \mathrm{~kg} \mathrm{~N} \mathrm{ha}^{-1}$ of goat manure.

Correlation matrix of different dependent variables of cucumber

Correlation matrix of different dependent variables of cucumber as influenced by goat manure application is presented in Table 3. Fruit length was positively and significantly correlated with fruit yield (0.893), LAI (0.677), number of fruit (0.764), number of leaves (0.624), vine length (0.643) and number of branches (0.561). Fruit yield was positively and significantly correlated with LAI (0.595), number of fruits (0.857), number of leaves (0.614), vine length (0.687) and number of branches (0.578). LAI was positively correlated with number of fruits, number of leaves, vine girth, vine length and number of branches $(0.595,0.615,0.879,0.783$ and 0.720 , respectively). Number of fruits per plant was significantly positively correlated with number of leaves $(\mathrm{r}=0.610)$, vine girth $(\mathrm{r}=$ $552)$, vine length $(r=0.783)$ and number of branches $(r=$ $0.700)$. Number of leaves was positively $(\mathrm{P}<0.05)$ correlated with vine girth $(\mathrm{r}=0.869)$, vine length $(\mathrm{r}=$ $0.892)$ and branches $(\mathrm{r}=0.794)$. Vine girth was positively and significantly correlated with vine length $(r=0.733)$ and number of branches $(r=0.617)$. There was significant positive correlation between vine length and number of branches $(r=0.865)$.

Table 2. Fruit yield and its components of $C$. sativum as influenced by different rate of goat manure application

\begin{tabular}{|c|c|c|c|c|}
\hline Goat manure & Fruit length & Fruit girth & No. of fruit/ & Fruit yield \\
\hline$\left(\mathrm{Kg} \mathrm{Nha}^{-1}\right)$ & $(\mathrm{cm})$ & $(\mathrm{cm})$ & plant $^{-1}$ & $\left(\right.$ th $\left.^{-1}\right)$ \\
\hline 0 & 11.97 & 10.41 & 2.23 & 12.34 \\
\hline 100 & 12.73 & 12.00 & 2.87 & 16.96 \\
\hline 200 & 12.76 & 12.21 & 2.66 & 20.85 \\
\hline 300 & 14.84 & 13.90 & 3.10 & 20.85 \\
\hline 400 & 15.24 & 14.55 & 4.20 & 26.21 \\
\hline $\operatorname{LSD}_{(0.05)}$ & 1.324 & 1.844 & 1.282 & 6.396 \\
\hline
\end{tabular}

Table 3. Correlation matrix of dependable variables of cucumber

\begin{tabular}{|c|c|c|c|c|c|c|c|c|}
\hline & Fruit length & Fruit yield & LAI & No. of fruits & No. of leaves & Vine girth & Vine length & No. of branches \\
\hline Fruit length & 1.000 & & & & & & & \\
\hline Fruit yield & $0.893^{*}$ & 1.000 & & & & & & \\
\hline LAI & $0.677^{*}$ & $0.595^{*}$ & 1.000 & & & & & \\
\hline No. of fruits & $0.764^{*}$ & $0.857^{*}$ & $0.595^{*}$ & 1.000 & & & & \\
\hline No. of leaves & $0.624^{*}$ & $0.614^{*}$ & $0.615^{*}$ & $0.610^{*}$ & 1.000 & & & \\
\hline Vine girth & 0.470 & 0.500 & $0.879^{*}$ & $0.552^{*}$ & $0.869^{*}$ & 1.000 & & \\
\hline Vine length & $0.643^{*}$ & $0.687^{*}$ & $0.783^{*}$ & $0.783^{*}$ & $0.892^{*}$ & 0.733 & 1.000 & \\
\hline No. of branches & $0.561^{*}$ & $0.578^{*}$ & $0.720^{*}$ & $0.700^{*}$ & $0.794^{*}$ & $0.617^{*}$ & $0.865^{*}$ & 1.000 \\
\hline
\end{tabular}

${ }^{*}$ - Significant at 0.05 level of probability 


\section{Discussion}

The soil of the experimental site was a typical ultisols as it was acidic sand with lower than critical values for essential plant nutrients as compared with critical level recommended by Ibedu et al. (1988). This implies that the soil has low fertility status. This observation was in agreement with Akanbi and Togun (2002) who reported that most Nigerian soils are low in inherent fertility, due to intense weathering, leaching and intensive cultivation. Consequently, optimum yield cannot be achieved without supplementary the soil nutrient through the application of fertilizer.

The analysis of goat manure showed that it contained appreciable quantity of plant nutrient. This is in agreement with Moral et al. (2005), who reported that organic fertilizers were as good as inorganic fertilizers for cucumber production. It contained high quantity of organic carbon. Since organic carbon is a reservoir of plant nutrients, on mineralization it will release more nutrients to the soil. Earlier studies by Ojeniyi et al. (1999), Smith and Ayenigbara (2001) showed that goat manure improved N, $\mathrm{P}, \mathrm{K}, \mathrm{Ca}$ and $\mathrm{Mg}$ status of soil. Application of goat manure is expected to improve the yield of cucumber. The significant higher yield traits of the goat manure fertilized plants could be attributed to enhanced plant nutrient from the goat manure (Ndaeyo et al., 2005).

Organic carbon apart from releasing nutrient elements to the soil, it also improve soil chemical and physical properties which enhance crop growth and development (Mbagwu and Ekwealor, 1990). In addition, organic carbon has also been reported to increase soil $\mathrm{pH}$ (Ullah et al., 2008), hence the acidic soil of the experimental site which might have caused the unavailability of nutrient element to the crops was checked by the liming potential of goat manure.

Increase in the number of leaves of fertilized plants compared to unfertilized plants indicated that increased nutrients in the soil increase number of leaves per plant. This was similar to the findings of Hamma et al. (2012) who observed the highest number of leaves in cucumber plants treated with $12 \mathrm{t} \mathrm{ha}^{-1}$, while the least number was recorded in those treated with $0 \mathrm{tha}^{-1}$. Higher number of branches observed with fertilized plant over no fertilized plants was an indication of higher nutrient uptake and implied higher number of leaves as indicated through positive correlation between the number of leaves and number of branches. Higher number of leaves gave rise to higher leaf area index. Higher leaf area index is an indication of higher light interception, which led to greater production and translocation of assimilates to the storage organ which is the fruit.

The study showed that the number of harvested cucumber fruits and its length were significantly boosted by goat manure application, as higher and longer fruits were produced by the fertilized plants, due to improved nutrient uptake. Decrease in fruit yield in control plots is due to the low fertility level of the soil and the improvement observed in the fertilized plots was as a result of the availability of nutrients in the soil, due to application of goat manure which expectedly led to increased uptake of N, P, K, Ca and $\mathrm{Mg}$; thus ultimately significantly increase crop growth and yield. These results agreed with Ayoola and Adeniran (2006) saying that variation in nutrients source among treatments will result in a significant variation on fruit length per plant in most crops. Better utilization of nutrients might also be the reason towards the increase in cucumber yield obtained in this study.

\section{Conclusions}

The results obtained from the present study showed that cucumber responded well to the application of goat manure. Goat manure application at 200, 300 and $400 \mathrm{~kg} \mathrm{~N} \mathrm{ha}^{-1}$ significantly increased the growth and yield of cucumber. Based on these findings, goat manures applied at $200 \mathrm{~kg} \mathrm{~N}$ $\mathrm{ha}^{-1}$ should be suggested for cucumber growers to minimize the cost of production and increase the yield of cucumber for profit maximization.

\section{References}

Akanbi WB, Togun AO, Adediran JA, Ilupeju EAO (2010). Growth, dry matter and fruit yield components of okra under organic and inorganic sources of nutrients. American-Eurasian Journal of Sustainable Agriculture 4(1):1-13.

Ayoola OT, Adeniran ON (2006). Influence of poultry manure and NPK fertilizer yield and yield components of crops under different cropping systems in South West Nigeria. African Journal of Biotechnology 5:1335-1392

Blanco FF, Folegatti MV (2003). A new method for estimating the leaf area index of cucumber and tomato plants. Horticultura Brasileira 21(4):666-669.

EADP (1995). Edo State Agricultural Development Project. Edo State Agricultural Development Project. Annual Report 1995.

EfeidiyiEKM, Remison SU (2009). The effects of inorganic fertiliser 101-21 on the yield of two varieties of cucumber (Cucumis sativus L.). Report and Opinion 1(5):74-80.

Hamma IL, Ibrahim U, Haruna M (2012). Effect of poultry manure on the growth and yield of cucumber (Cucumis sativum $\mathrm{L}$.) in Samaru, Zaria. Nigerian Journal of Agriculture, Food andEnvironment 8(1):9498.

Ibedu MA, Unamba RPA, Udealor A (1988). Soil management strategies in relation to farming system development in the southeastern agricultural zone of Nigeria. Paper Presented at the National Farming Systems Research Workshop, Jos, Plateau State, Nigeria, 26-29 April pp 20.

Mbagwu JSC, Ekwealor GC (1990). Agronomic potential of brewers spent grains. Boil Wastes 34:335-347.

Moral R, Moreno-Caselles J, Perez MN, Espinosa P, Pardes C, Sosa F (2005). Influence of fresh and composted slurry fraction of swine slurry on the yield of cucumber (Cucumis sativus L.). Communications in Soil Science and Plant Analysis 36(416):517-524.

Ndaeyo NU, Ukpong ES, John NM (2005). Performances of okra as affected by organic and inorganic fertilizers on an utisol. Proceedings of the 39th Conference of the Agricultural Society of Nigeria, October 913 pp 206-209.

Ojeniyi SO (2000).Effect of goat manure on soil nutrients and okra yield in a rain forest area of Nigeria. Applied Tropical Agriculture 5:20-23. 
232

Orzolek MD, Kima LF, Bogash SM, Harper JK (2010). Agricultural alternative: cucumber production. Agricultural Research and Cooperation Extension Bulletin, Pennsylvania State University, UA463.

Pahla I, Tagwira F, Muzemu S, Chitamba J (2013). Effects of soil type and manure level on the establishment and growth of Moringa oleifera. International Journal Agriculture and Forestry 3(6):226-230.

Phu Tatlioglu NT (1997). Nitrogen and potassium effect on cucumber yield. AVI 1996 report, ARC/AVRDC Training Thailand.

Remison SU (1997). Basic principles of crop physiology. Sadoh Press, Benin City,Nigeria.

Reddy KR, Kadlec R (2005a). Biogeochemistry of phosphorous in wetlands. Phosphorous: Agriculture and the Environment Phosphorusagric 263316.
Smith MAK, Ayenigbara EA (2001). Comparative growth and nutrient composition of Indian spinach in an enriched humid tropical environment. African Crop Science Conference. Proceedings 5:10071013.

Ullah MS, Islam MS, Haque T (2008). Effects of organic manure and chemical fertilizers on the yield of brinjal and soil properties. Journal Bangladesh Agricultural University 271-276.

USDA (2004). Cucumbers: An economic assessment of the feasibility of providing multi-peril crop insurance. Economic Research Service.

Van Luijik MN (2004). Cucumis sativus L. In: Grubben GJH, Denton OA (Eds). PROTA 2: Vegetables / Legumes (CD - ROM), Wagenigen, Netherlands. 